\title{
AUTOMATED MEASUREMENT AND SYSTEM DATA LOGGER FOR CONTINUOUS MONITORING OF SLICED BANANA FRUIT DURING DRYING PROCESS BY A SOLAR HOT- AIR DRYER
}

\author{
Entsar A. Saber ${ }^{1}$, El-Attar ${ }^{1}$ M.Z., Mostafa ${ }^{1}$ M.M. and Heikal ${ }^{2}$ Y.A.
}

1. Agric. Engineering Dept., Fac. of Agric., Ain Shams Univ., P.O. Box 68, Hadyek Shoubra, 11241, Cairo, Egypt

2. Food Sci. Dept., Fac. of Agric., Ain Shams Univ., P.O. Box 68, Hadyek Shoubra, 11241, Cairo, Egypt

*Corresponding author: entsarelattar1992@yahoo.com

Received 28 February, $2019 \quad$ Accepted 23 March, 2019

\section{ABSTRACT}

The aim of this work is developing and evaluating an automated measurement and system datalogger for continuous monitoring of solar hot air drier for natural convection solar cabinet drier. Measurements includes monitoring of drying process for sliced Banana (Musa acuminata) relation to weather parameters such as ambient air temperature, relative humidity and wind velocity which ensures precise measurements and reproduction of experiments. An electronic measurement system was used for measurement of temperature, humidity, air speed, a solar intensity. A programmable microcontroller ship and code were used to control measurement, timing, and data storage twenty-four hours/day. All measurements data was collected and saved in storage memory card. Results showed that the solar drier drying rate achieved $(-0.018 \mathrm{gH} 2 \mathrm{O} / \mathrm{g} \mathrm{dm} . \mathrm{h})$, while the drying rate with mean of electrical thermal drier were $(-0.956 \quad 018 \mathrm{gH} 2 \mathrm{O} / \mathrm{gdm} . \mathrm{h})$ at $105^{\circ} \mathrm{C}, \quad(-0.552$ $018 \mathrm{gH} 2 \mathrm{O} / \mathrm{g} \mathrm{dm} . \mathrm{h})$ at $70^{\circ} \mathrm{C}$ and $(-0.513$ $018 \mathrm{gH} 2 \mathrm{O} / \mathrm{gdm} . \mathrm{h})$ at $50^{\circ} \mathrm{C}$. The electronic measurement - datalogging system was able to give an accurate measurement and assessment to the drying system and process. It was found that air leakage from the system and poor insulation inhibit the airflow over the solar absorber plate and drying chamber causing thermal leakage form the bottom and drier sides. It was recommended to supply the solar drier with an air fan, seal the drying air leakage, and air-lock at the entrance to control airflow as well as the temperature of the drying process.
Keywords: solar drier, Banana, automated measurement and data logging system.

\section{INTRODUCTION}

Today, one of the main global challenges is how to ensure food security for a world growing population whilst ensuring long-term sustainable development. According to the FAO 2014, food production will need to grow by $70 \%$ to feed world population which will reach 9 billion by 2050 (Aulakh and Regmi, 2013). During a research prioritization exercise undertaken by Food Security and Livelihoods sector in 2011, postharvest handling was recognized as one of the important areas requiring attention. It is of high importance in the effort to combat hunger, raise income and improve food security (Kiaya, 2014). A complex series of metabolic adjustments occur in vegetables after harvest which are influenced by dislocation of supply of nutrients, water and growth regulators from the parent plant to the harvested vegetables. The overall process leads to postharvest deterioration of the produce. However, the losses can be reduced with adoption of postharvest management and use of processing technology of vegetable crops. (Magray et al 2017). Banana mass cultivation and consumption in the recent decades made it the world second largest fruit crop, in 2012 the volume of global gross banana exports reached a record high of 16.5 million tones, 1.1 million tones (or 7.3 percent) above 2011 level( FAO, 2014).

The fruit processing industry is one of the major businesses in the world. While basic principles of 
fruit processing have shown only minor changes over the last few years, major improvements are now continuously occurring, and more efficient equipment capable of converting huge quantities of fruits into pulp, juice, dehydrated, frozen, refrigerated products, etc. make possible the preservation of products for year-round consumption(ElRamady et al 2015). Stover and Simmonds (1987) stated that banana is a major important crop in the developing world and consumed as energy yielding food or as a dessert. They estimated that banana crop provides nearly 60 million people in Africa with more than 200 calories (food energy) a day. Drying is the most common and cheap method of processing fruits and vegetables (Hassan, 2010). Drying is one of the oldest methods of preserving food. Primitive societies practiced the drying of meat and fish in the sun long before recorded history. Today the drying of foods is still important as a method of preservation. Dried foods can be stored for long periods without deterioration occurring (Earle, 1983). Safe moisture content (SMC) is the extent to which moisture can be withdrawn from food crops during drying that such crops can be considered safe for storage with minimal loss of nutritional qualities (Afolabi, 2014).

Price, (2007) showed that harvest season and hence initial moisture content has a very marked influence on the drying kinetics. By contrast banana maturity (ripeness) has little influence on the kinetics despite there being significant differences in morphology and chemical composition between green and ripe bananas. Initial moisture content varied with bananas of different harvesting seasons. The large difference in initial moisture content (over $5 \%$ wet basis) could strongly affect drying rates. However, this effect was only clearly observed at low temperature $\left(40 \mathrm{C}^{\circ}\right)$ (Price, 2007 and Joardder et al 2014). The longer life attained by drying is however accompanied by huge energy consumption and deterioration of quality.

Sun drying is a well-known traditional method of drying agricultural commodities immediately after harvest. However, it is plagued with in-built problems, since the product is unprotected from rain, storm, windborne dirt, dust, and infestation by insects, rodents, and other animals. The solar dried products have much better color and texture as compared to open sun-dried products. The justification for solar driers is that they dry products rapidly, uniformly and hygienically, the traits inevitable for industrial food drying processes (Perum et al 2007) .Drying is a complex process in which heat and mass transfer occur simultaneously. It is important to understand the parameters controlling this complex process and to understand the drying behavior of a given product for use in improving the existing drying systems, controlling the drying process and improving on the quality of the dried product (Kawongolo, 2013).

The main of the present research is developing and evaluate an automated measurement and system datalogger for continuous monitoring of solar hot air drier for natural convection solar cabinet drier. Measurements includes monitoring drying process for sliced Banana (Musa acuminata) relation to weather parameters such as ambient air temperature, relative humidity, wind velocity. which ensures precise measurements and reproduction of experiments.

\section{MATERIALS AND METHODS}

The solar air drier was fabricated and tested in Ain Shams University, Faculty of Agriculture, Agricultural Engineering Department, Cairo, Egypt, Latitude: $+30.06\left(30^{\circ} 03^{\prime} 36^{\prime \prime} \mathrm{N}\right)$, Longitude: +31.25 (31'15'00"E), Altitude: $\sim 20 \mathrm{~m}$. The field experiments were conducted on August 2018.

\section{Solar drier construction and dimensions}

Solar collector, the absorber plate of the collector is a black painted galvanized steel sheet of dimensions ( $2 \mathrm{~m}$ in length and $1 \mathrm{~m}$ in width). It was painted with a mat black paint in order to increase its absorptivity. The collector glass cover is a single glass cover with thickness of $0.6 \mathrm{~cm}$ and its frame made from an aluminum sheet the distance between the glass cover and the absorber plat was of $4 \mathrm{~cm}$ along the collector, which made the air passage. Glass wool was used as an insulating material for all collector sides. The body of the collector was made from galvanized steel sheets, collector air vent was covered by wire mesh. It was investigated with a fixed inclined of $30^{\circ}$ from the horizontal and oriented it towards the south direction as depicted in Figs. 2, 3 and 4.

Drying chamber, The drying chamber is a wooden room with dimensions of $(0.6 \mathrm{~m}$ long, $0.6 \mathrm{~m}$ wide and $1 \mathrm{~m}$ high). Heat loss by conduction is reduced by using glass wool of $0.6 \mathrm{~cm}$ thick was used as an insulation material for all chamber sides. Its capacity is Six kilograms of fresh banana slices was peeled and cut to slices as it was spread on a drying trays the dried banana slices were spread in a drying tray made of an aluminum wire mesh with an area of $\left(57^{\star} 50 \mathrm{~cm}\right)$.It has three trays, as shown in Fig. 5. 


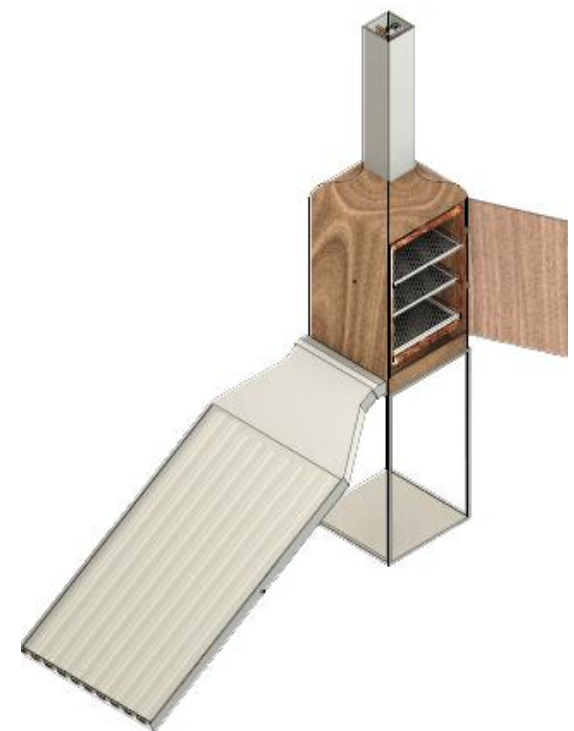

(B) solid view

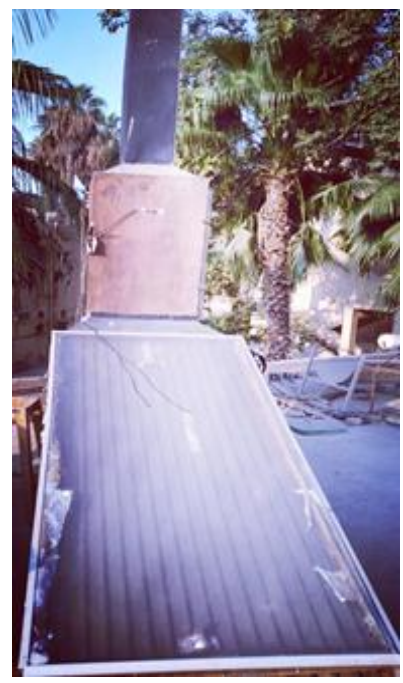

(A) photograph

Fig. 1. The experimented solar dryer

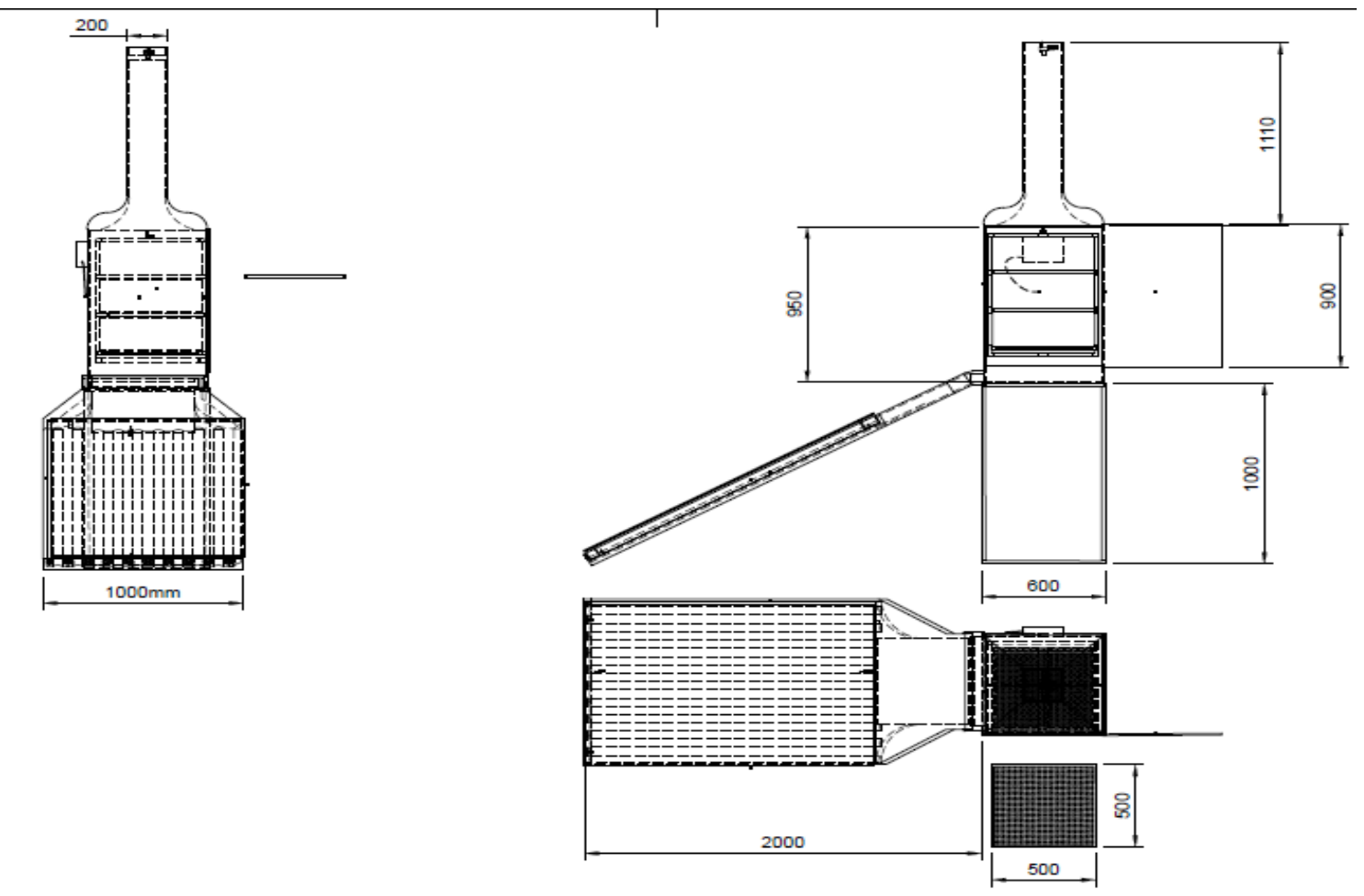

Fig. 2. Engineering drawing of the experimented Solar drier dimensions 

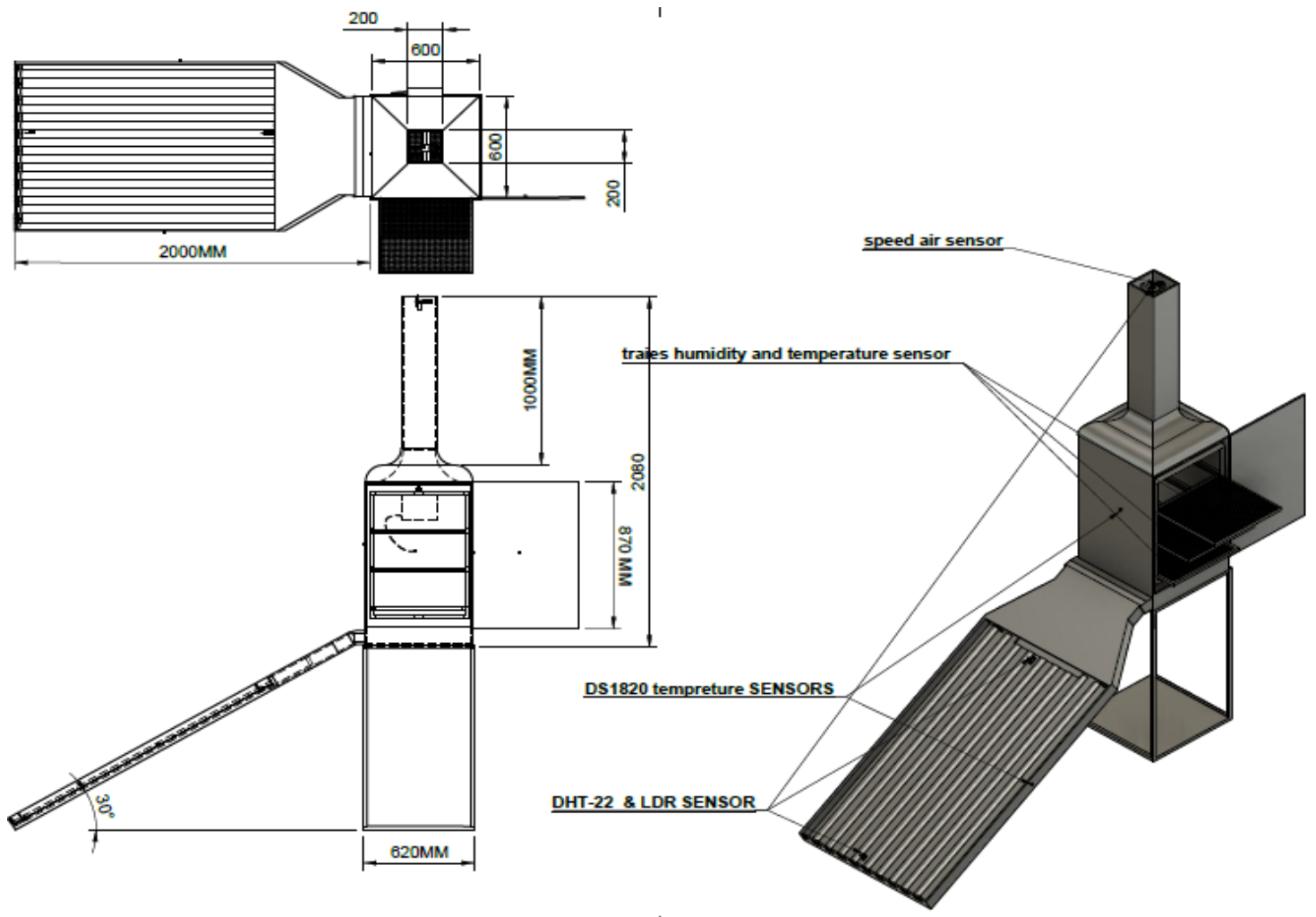

Fig. 3. Perspective view of the experimented solar drier
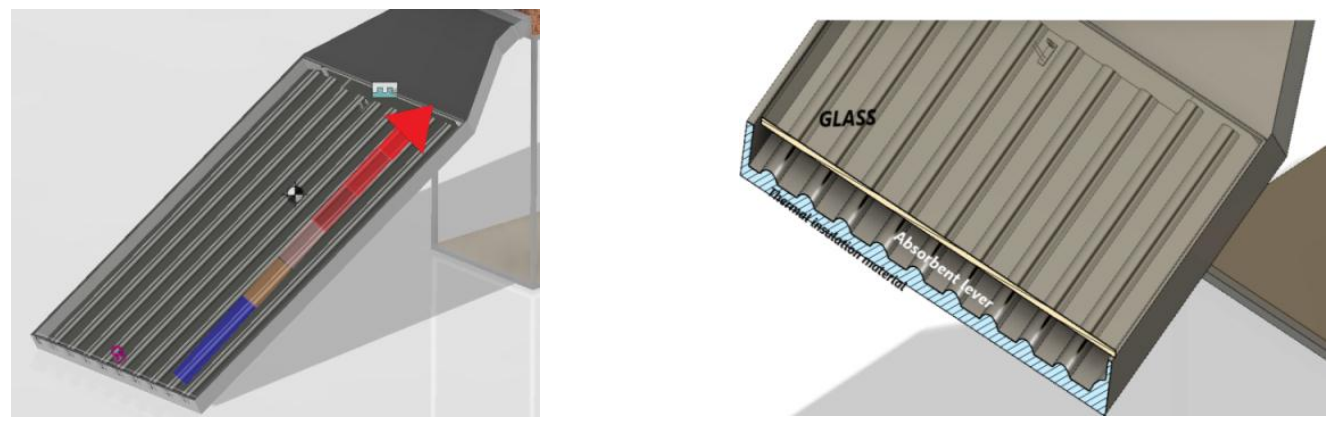

Fig. 4. Solar collector and orientation
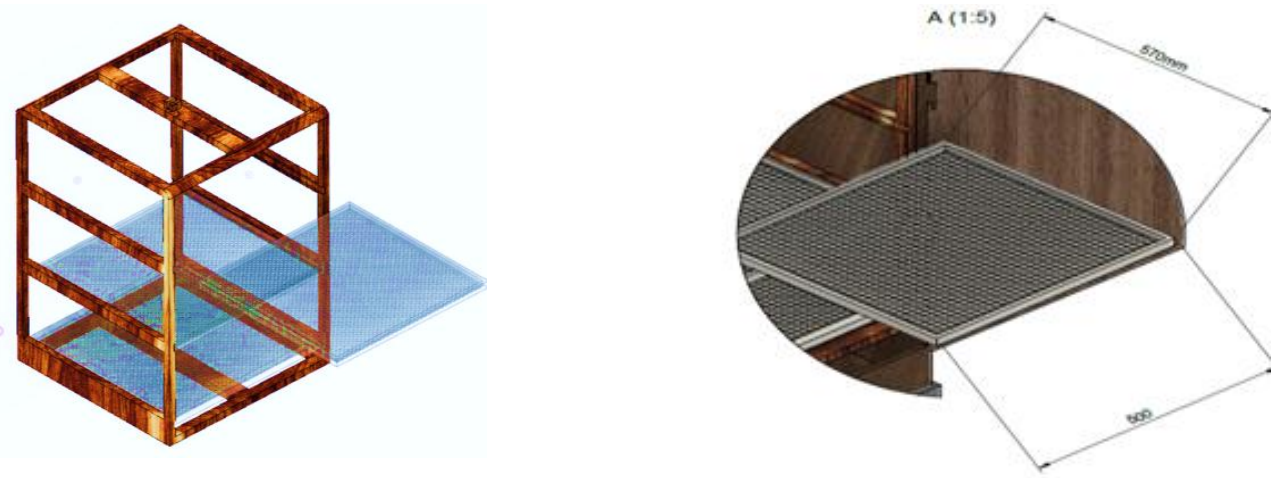

Fig. 5. Drier trays dimensions and layout 
Fresh and dried material quality evaluation: Banana (Musa sp.) cultivars grown in Egypt
Physical properties: shape and dimensions as shown in Fig. 6.

Banana

water content $75 \%$
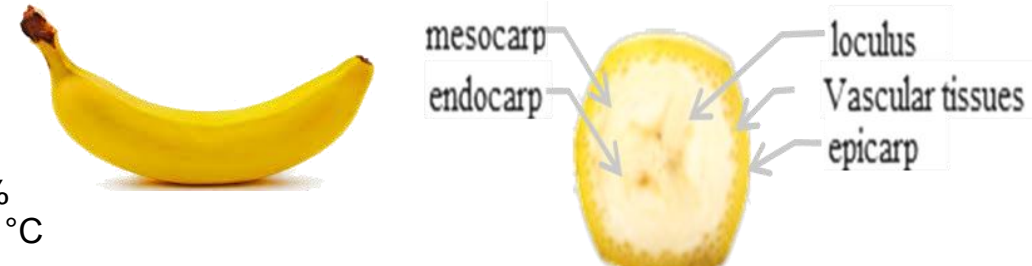

Fig. 6. structural and cross section of banana slice

Thermo-physical attributes: The specific heats of foods can be expressed by Siebel's formula as

$C_{p_{\text {fresh }}}=3.35$ a 0.48 Equation(1)
Where $\llbracket C p \rrbracket$ fresh is the specific heats of the food $\left(\mathrm{kJ} /\left(\mathrm{kg}{ }^{\circ} \mathrm{C}\right)\right)$, a is the fraction of water content of the food (a 0.65 if the water content is 65 percent), and the constant $0.84\left(\mathrm{~kJ} / \mathrm{kg}{ }^{\circ} \mathrm{C} \_p\right)$ represents the specific heat of the solid (nonwatery) portion of the food.

Table 1. Properties of bananas, fresh

\begin{tabular}{|c|c|c|c|c|c|}
\hline Water content & Temperature & Density & \multicolumn{2}{|c|}{ Thermal } & Specific heat \\
\hline$\%$ (mass) & ${ }^{\circ} \mathrm{C}$ & $\mathrm{Kg} / \mathrm{m}^{3}$ & Conductivity & diffusivity & $\mathrm{WJ} / \mathrm{kg} . \mathrm{K}$ \\
76 & 27 & 980 & 0.481 & $0.14 \times 10^{-6}$ & 3.59 \\
\hline
\end{tabular}

The specific and latent heats of foods depend on their water content alone. The heat transfer $Q$ from the food can be determined according to

$$
\begin{aligned}
& Q=m\left(h_{\text {initial }}-h_{\text {final }}\right) \\
& =m\left(h_{1}-h_{2}\right) \ldots \ldots \ldots \ldots \ldots \ldots \ldots \ldots \ldots \text { Equation }(2)
\end{aligned}
$$

where $\boldsymbol{m}$ is the mass of the food, $\boldsymbol{h}_{\text {initial }}$ and $\boldsymbol{h}_{\text {final }}$ are the initial and final enthalpies of the food, respectively $(\boldsymbol{k J}$,$) .$

\section{Sample texture Profile Analysis (TPA).}

The single column materials testing machines Tinius Olsen Model $\mathrm{H} 5 \mathrm{~K}$ was used to measure food stiffness and penetration force with load measurement accuracy by $\pm 0.5 \%$ of applied load from 2- $100 \%$ capacity; extended range down to $1 \%$ capacity with an accuracy of $1 \%$ of applied load, position measurement accuracy by $\pm 0.01 \%$ of reading $(0.001 \mathrm{~mm})$, and speed accuracy by $\pm 0.005 \%$ of set speed as shown in Fig. 7 .

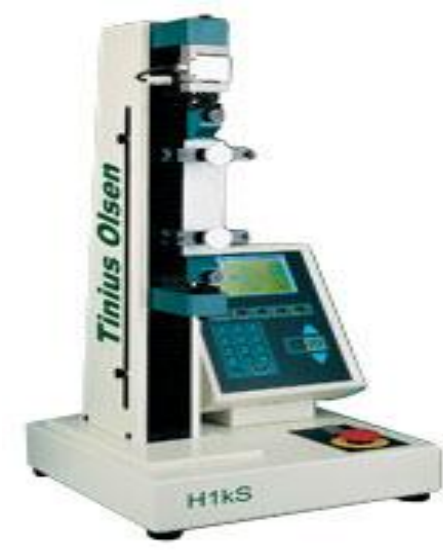

Fig. 7. Tinius Olsen bench top universal testing machine (UTM) 
Measurements, data logging, and data storage system: A customize system for measurement, datalogging, and data storage hardware and computer software was constructed for monitoring the environmental factors, solar energy harvest rate, and drying process, day and night every 30 seconds to the end of the drying process. The system consists of a programmable microcontroller
(ATmega2560 with 256 KB flash memory, SRAM 8 $K B$, and $16 \mathrm{MHz}$ process speed.

Datalogging and storage (SD module): The MicroSD Card module is a micro SD card reader : module for reading and writing through the file system. Fig. (8) describes the construction and wiring of the MicroSD module.

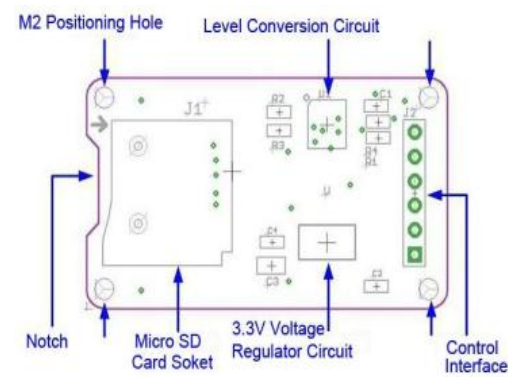

Fig. 8. The micro SD card interface module

Datalogging date and time (RTC module): For measurement date and time logging, serial realtime clock RTC was used. Based on DS1307, the RTC clock/calendar provides seconds, minutes, hours, day, date, month, and year information. The $R T C$ has a built-in power-sense circuit that detects power failures and automatically switches to the backup supply as shown in Fig. $\mathbf{9}$.

Banana measurement: A load cell $(20 \mathrm{~kg}$ capacity, strain gauge type), housed in aluminum alloy, Precision $0.05 \%$ operating temperature range -20 to $\sim 55^{\circ} \mathrm{C}$, and rated output $1.0 \pm$ $0.15 \mathrm{mv} / \mathrm{V}$.

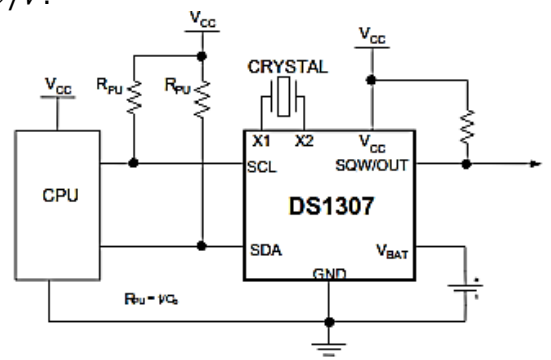

Fig. 9. Date and time logging, RTC module

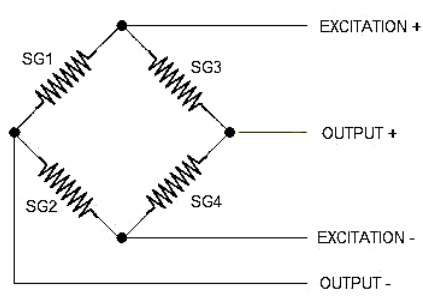

A twenty-kilogram Load cell
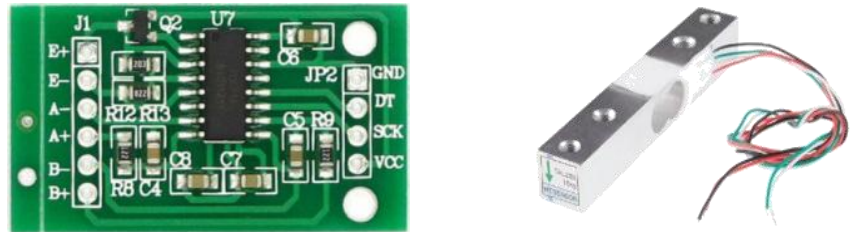

A Wheatstone bridge $H X 711$ Weight Scale analog to digital Converter

Fig. 10. A twenty-kilogram load cell, and the HX711 weight scale analog-to-digital converter

The load cell measurement signal was conditioned by the HX711 - weight scale analog-to-digital converter (ADC) within 24-bit data accuracy.
Load cell calibration procedures: Load cell has a rated output of $1.0 \pm 0.15 \mathrm{mv} / \mathrm{v}$ which corresponds to the sensor's capacity of $20 \mathrm{~kg}$. To find A for the load cell 
Force $_{\text {measured }}=\mathrm{A} \times\left(\frac{\mathrm{mV}}{\mathrm{V}}\right)_{\text {measured }}+\mathrm{B}_{\text {offset }}$

Equation (3)

$A=\frac{\text { (Capacity) }}{\text { Rated Output }}$ Equation (4)

Since the offset is quite variable between individual load cells, it's necessary to calculate the offset for each sensor.

Measuring the output of the load cell with no force on it and recording the $m v / V$ output. Off set reading of the load cell can be found according to the relation

Offset $=$

$0-20 *$ (Measured Output) ..Equation(5),

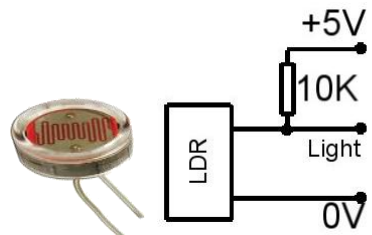

The load cell ( $20 \mathrm{~kg}$ capacity) factor was equals to 108.4 , according to calibration and software.

Solar intensity measurement: The solar intensity was measured with LDR (Light Dependent Resistor) sensor, calibrated with the solar radiation meter model MAC SOLAR SLM018C-E, Fig. (12). According to the manufacturer datasheet it was found the $L D R$ simulate and response to changes in the solar ray intensities during the day. The $L D R$ measurement configuration and its response to solar radiation is illustrated in Fig. (11).

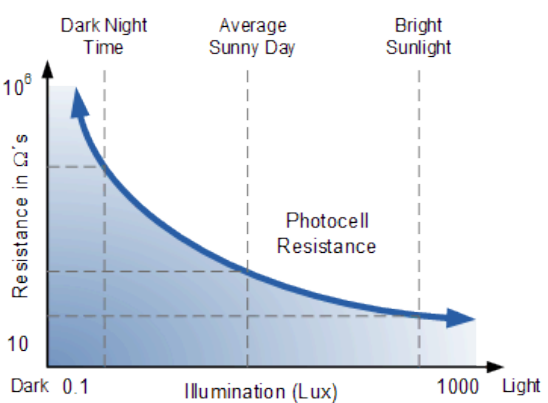

Fig. 11. Light dependent resistor for continuous solar radiation intensity circuit layout

Solar intensity $=\frac{500}{\mathrm{R}_{\mathrm{LDR}}(\mathrm{k} \Omega)} \ldots \ldots \ldots \ldots \ldots$. Equation (6)

$\mathrm{V}_{\text {out }}=\frac{5\left(\mathrm{R}_{\mathrm{LDR}}\right)}{\left(10+\mathrm{R}_{\mathrm{LDR}}\right)} \ldots \ldots \ldots \ldots \ldots \ldots \ldots$ Equation $(7)$

For a reference resistor other than $10 \mathrm{k} \Omega$ the solution is as follows

$R_{L D R}=\frac{\left(R_{\text {ref }} \times V_{\text {out }}\right)}{\left(5-V_{\text {out }}\right)} \ldots \ldots \ldots \ldots \ldots \ldots \ldots$ Equation (8) equation was used to convert lux readings into $\left(W / m^{2}\right)$
$P(W)=\frac{E v(l x) \times A\left(m^{2}\right)}{\eta\left(\frac{l m}{W}\right)} \ldots \ldots \ldots \ldots \ldots \ldots \ldots$ Equation $(9)$

where power $\boldsymbol{P}$ in watts $(W)$ is equal to the illuminance $\boldsymbol{E}_{-} \boldsymbol{v}$ in lux (Ix) times the surface area $\boldsymbol{A}\left(\mathrm{m}^{2}\right)$, divided by the luminous efficacy $\boldsymbol{\eta}$ in lumens per watt $(\mathrm{Im} / \mathrm{W})$ :

Solar radiation meter model MAC SOLAR $S L M 018 C-E$, was used to calibrate the LDR solar intensity sensor. The meter overall accuracy is $T<3 K \pm 1$ digit $\left(-25 \sim+75^{\circ} \mathrm{C}\right)$ and resolution by one Watt per square meter (Fig. 12).

\begin{tabular}{c|c|c} 
& $\mathbf{P}_{\text {tot }}$ & $\mathbf{T}$ \\
\hline Unit & $\mathrm{W} / \mathrm{m}^{2}$ & ${ }^{\circ} \mathrm{C}$ \\
\hline values & $0 \ldots 1500$ & $-40 \ldots+85$ \\
\hline Resolution & 1 & 0.1
\end{tabular}

Fig. 12. Solar radiation meter model MAC SOLAR SLM018C-E, Germany

Temperature measurement: Temperature was measured by a programmable series of a digital temperature sensor model DS1820 with resolution of $0.0001{ }^{\circ} \mathrm{C}$, measuring range from $-55^{\circ} \mathrm{C}$ to + $125^{\circ} \mathrm{C}$, and accuracy ranged from $-10^{\circ} \mathrm{C}$ to + $85^{\circ} \mathrm{C}$. The flow chart of the sensor showed in Fig. (13). Sensor model DS1820 and multiple unit connection showed in figure (14).Sensor resolution 
can be selected among various values showed in Table (2)

Table 1. Temperature measurement resolution selection

\begin{tabular}{|c|l|c|}
\hline $\begin{array}{c}\text { Resolution } \\
\text { (bit) }\end{array}$ & $\begin{array}{c}\text { Increment } \\
\left({ }^{\circ} \mathbf{C}\right)\end{array}$ & $\begin{array}{c}\text { Response time } \\
(\mathbf{m s})\end{array}$ \\
\hline 9 & 0.5 & 93.75 \\
10 & 0.25 & 187.5 \\
11 & 0.125 & 375 \\
12 & 0.0625 & 750 \\
\hline
\end{tabular}
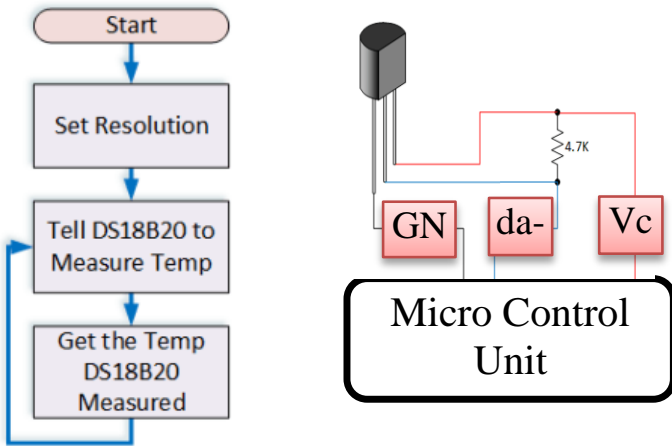

Fig.13. Flow chart of Temperature measurement algorithm

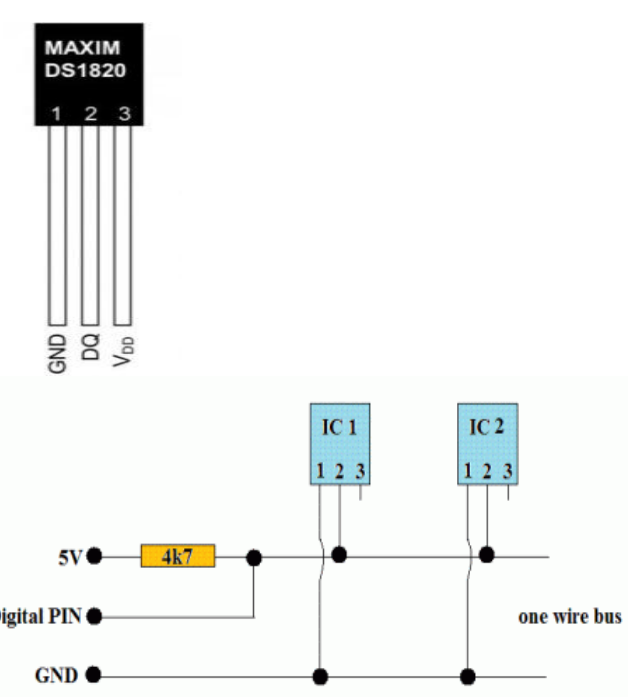

Fig. 14. A digital temperature sensor model DS1820 and multiple unit connection.

Humidity measurement Digital-output relative humidity and temperature Polymer capacitor sensor module, made by Aosong Electronics Co., Ltd. according to the manufacturing, DHT22 sensor is temperature compensated and calibrated in accu rate calibration chamber and the calibrationcoefficient is saved in type of programmed in OTP memory. DHT22 sensor specifications are listed in Table (3) and showed in Fig.15.

Table 2. DHT22 digital humidity and temperature measurement specifications

\begin{tabular}{|c|c|c|}
\hline $\begin{array}{c}\text { Sensor } \\
\text { DHT22 }\end{array}$ & Humidity & Temperature \\
\hline $\begin{array}{c}\text { operating } \\
\text { range } \\
\begin{array}{c}\text { Resolution } \\
\text { Accuracy }\end{array}\end{array}$ & $\begin{array}{c}0-100 \% \mathrm{RH} \\
\pm 2(\mathrm{Max} \\
\pm 5 \% \mathrm{RH})\end{array}$ & $-40 \sim+80^{\circ} \mathrm{C}$ \\
\hline
\end{tabular}
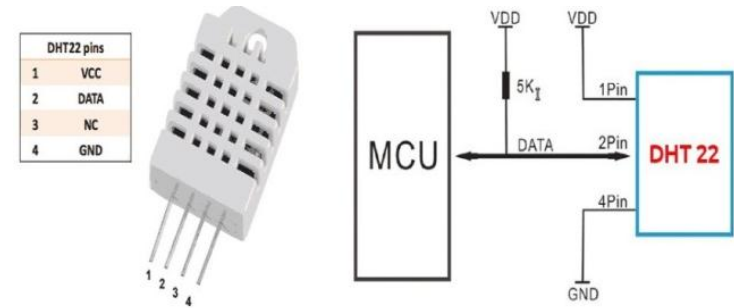

Fig.15. Temperature and humidity measurements, DHT22 module.

Air speed meter (anemometer): A Uni-T Ut363 Mini Anemometer air velocity was used to measure the ambient and drier air velocity with speed range $0-30 \mathrm{~m} / \mathrm{s}$, resolution $0.1 \mathrm{~m} / \mathrm{s}$, and accuracy $\pm(5 \%$ rdg +0.50$)$ as shown in Fig.(16).

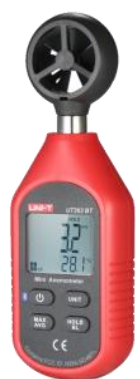

Figure16: Uni-T Ut363 Mini Anemometer air velocity

The device resolution was enhanced to sense one sixth of the fan revolution instead of sensing one revolution, by adding TCRT5000 fan reflective optical sensor with amplifier output and new resolution of $0.017 \mathrm{~m} / \mathrm{s}$ as shown in Fig. (17). The modified air speed configuration was calibrated with the $\mathrm{BK}$ precision thermo-anemometer model $731 \mathrm{~A}$ as shown in Fig. (18). 

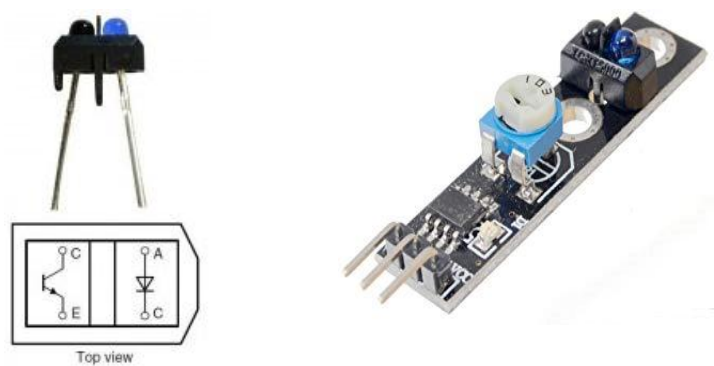

Fig. 17. TCRT5000 reflective optical module.
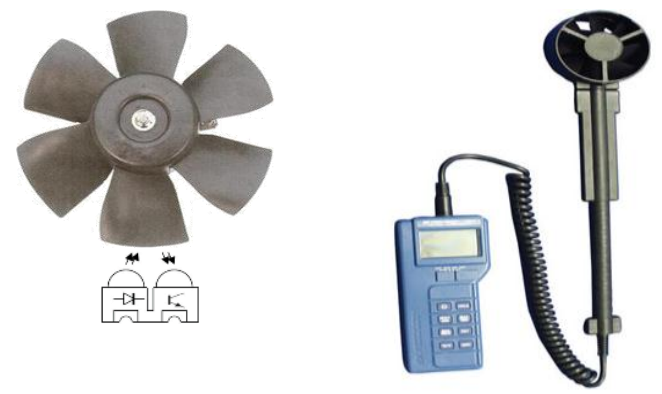

\begin{tabular}{ccc} 
BK 731A & Air speed & Temperature \\
\hline $\begin{array}{c}\text { operating } \\
\text { range } \\
\text { Resolution }\end{array}$ & $0 \sim 30 \mathrm{~m} / \mathrm{s}$ & $-20 \sim 60^{\circ} \mathrm{C}$ \\
Accuracy & $0.01 \mathrm{~m} / \mathrm{s}$ & $0.1^{\circ} \mathrm{C}$ \\
& $\pm 3 \% \mathrm{FS}$ & $\pm 0.5^{\circ} \mathrm{C}$ \\
\hline
\end{tabular}

Fig. 18. Air velocity resolution enhancement and installation, and BK precision thermo-anemometer model 731A.

Solar drier performance evaluation and analysis: Solar drier efficiency indicates the overall thermal performance of a drying system including the efficiency of the solar collector, the drying chamber and any other supplement add to the system. In the work done in our lab, Microsoft Excel $\AA$ spreadsheets were used for all data manipulations and calculations spreadsheets to develop equations for curves.

Solar flat plate collector: Air enters the constant spacing between the glass cover and the plate of a solar collector. The net rate of heat transfer and the temperature rise of air were determined according to Assumptions 1) Steady operating conditions exist. 2). The inner surfaces of the spacing are smooth. 3) Air is an ideal gas with constant properties. 4). The local atmospheric pressure is 1atm (Struckmann, 2008).

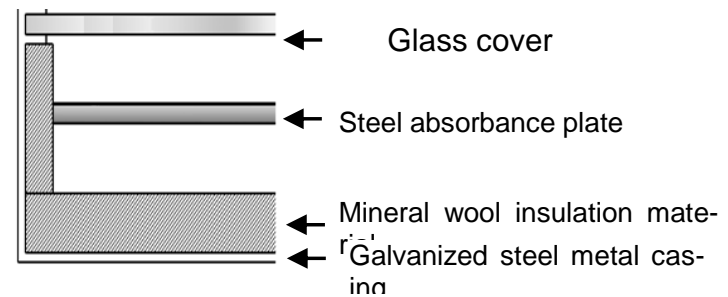

Fig. 19. Flat plate collector absorber plate cross section

To minimize the heat losses from the FPC according to previous equations, a wooden frame and glass-wool layers were used to cover back and sides of the collector. Heat transfer overall thermal conductivity will be the sum of the values of conductivity of air, wood glass wool, and absorber layers showed in Fig. (19).

Drying Experiment: Bananas were peeled, weighed using a laboratory-scale ME-YP with resolution $0.1 \mathrm{~g}$, and cut into cylindrical pieces of thickness $1 \mathrm{~cm}$ weighted 2.5 grams of ripe bananas, without any thermal or chemical treatments, were used in each experiment. Fruit was placed on a steel mesh tray, which was suspended from an electronic balance. The balance output to a computer- based data acquisition system recorded automatically the mass change, temperature, and humidity of surrounding air as a function of drying time.

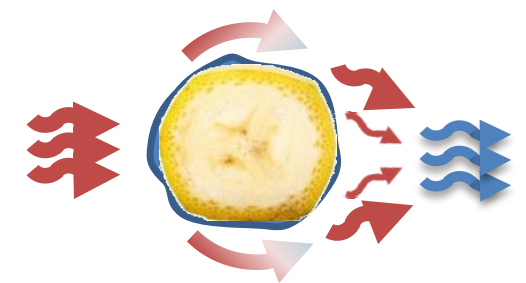

Fig. 20. Illustration of heat and mass transfer from the sample

Moisture Content Determination: Initial moisture contents of three replications of banana slices were determined on dry basis and as a moisture ratio as indicated in the flowing equations:

at Wet Basis Moisture content, $\%=$ $\frac{\text { weight of water removed }}{\text { total weight of wet material }}(\mathrm{kg}$ of water $/ \mathrm{kg}$ of dry matter)..................Equation( 10)

at dry basis moisture content, $\%=$ $\frac{\text { weight of water removed }}{\text { weight of dry solids }}(\mathrm{kg}$ of water $/ \mathrm{kg}$ of solids) ...................Equation(11)

Moisture ratio $=\frac{\text { Dry basis moisture at time }}{\text { Initial dry basis moisture }}$ Equation(12)

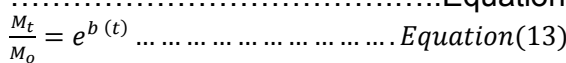

where $\boldsymbol{M}_{\boldsymbol{t}}$ is the moisture content of sample at time $(t), \boldsymbol{M}_{o}$ is the initial moisture content, and $\boldsymbol{b}$ is the rate of moisture removal from the sample. 


\section{RESULTS AND DISCUSSION}

The solar drier was designed and experimented to work at natural convection airflow. Results indicate a notable low air-flow through the drier with increasing thermal losses from the solar collector bottom and sides at daylight, which leads to assumption of an ambient air leakage with a tight airflow ducts between the drier chamber and the solar collector.

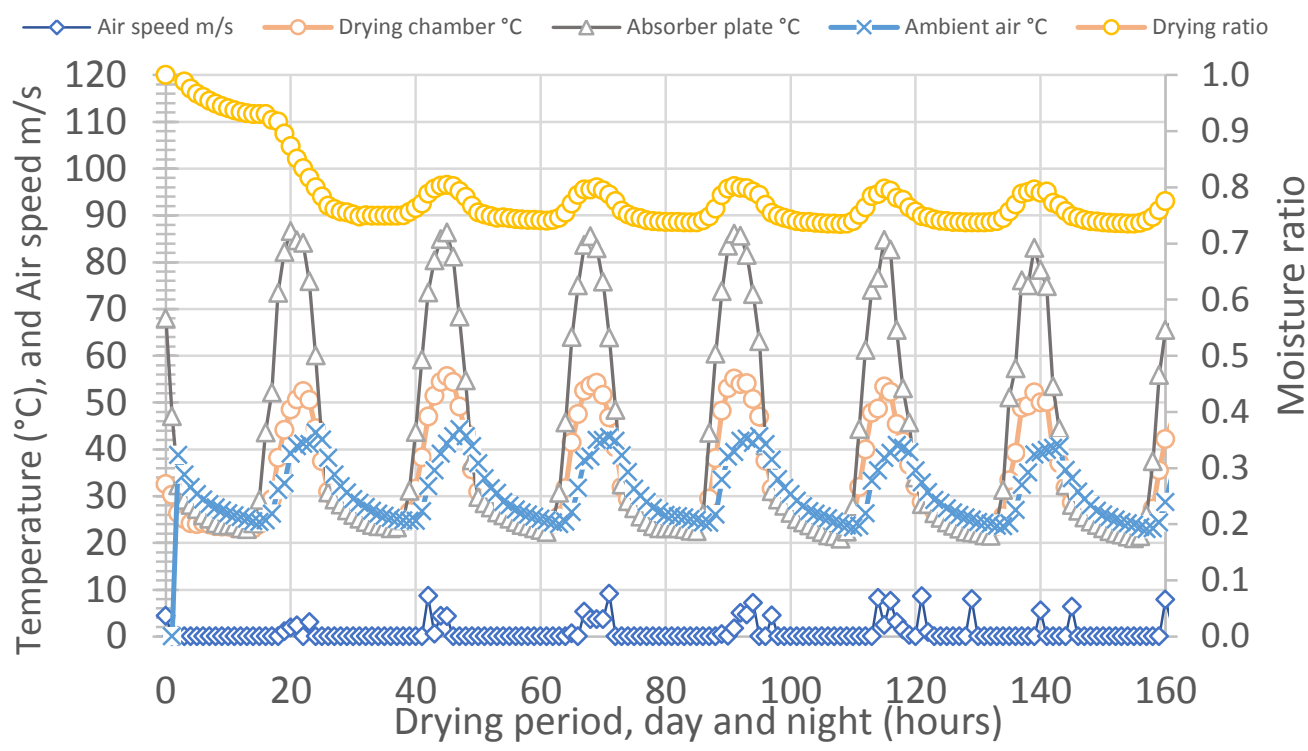

Fig. 21. Drying chamber temperature $\left({ }^{\circ} \mathrm{C}\right)$ and banana slices moisture ratio in relation to ambient, air temperature $\mathrm{e}\left({ }^{\circ} \mathrm{C}\right)$, absorber plate temperature $\left({ }^{\circ} \mathrm{C}\right)$, and drying chamber convicted hot air speed $(\mathrm{m} / \mathrm{s})$.

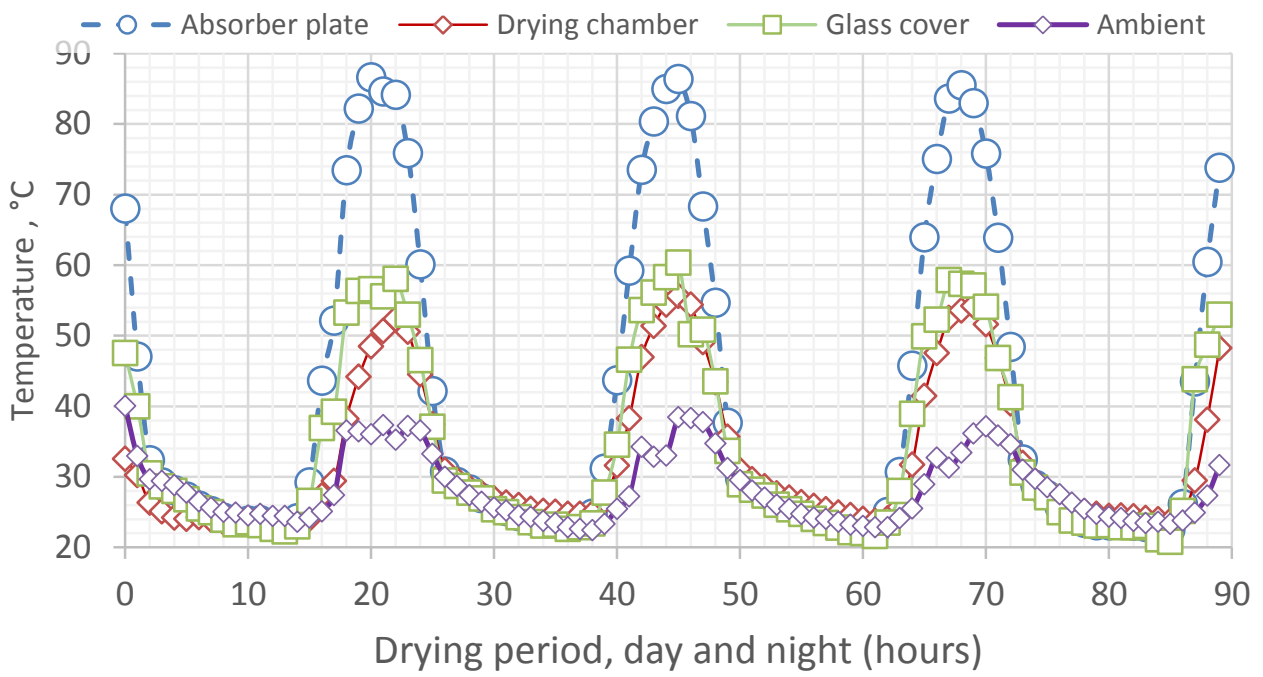

Fig. 22. Temperature difference between ambient air, collector steel plate absorber, absorber plate glass cover, and drying chamber

Ambient air relative humidity intervenes with rate of moisture content removal from the banana slices and corelate with the air temperature flow with the drying chamber as shows in Fig. (23). 

banana fruit during drying process by a Solar Hot- Air Dryer

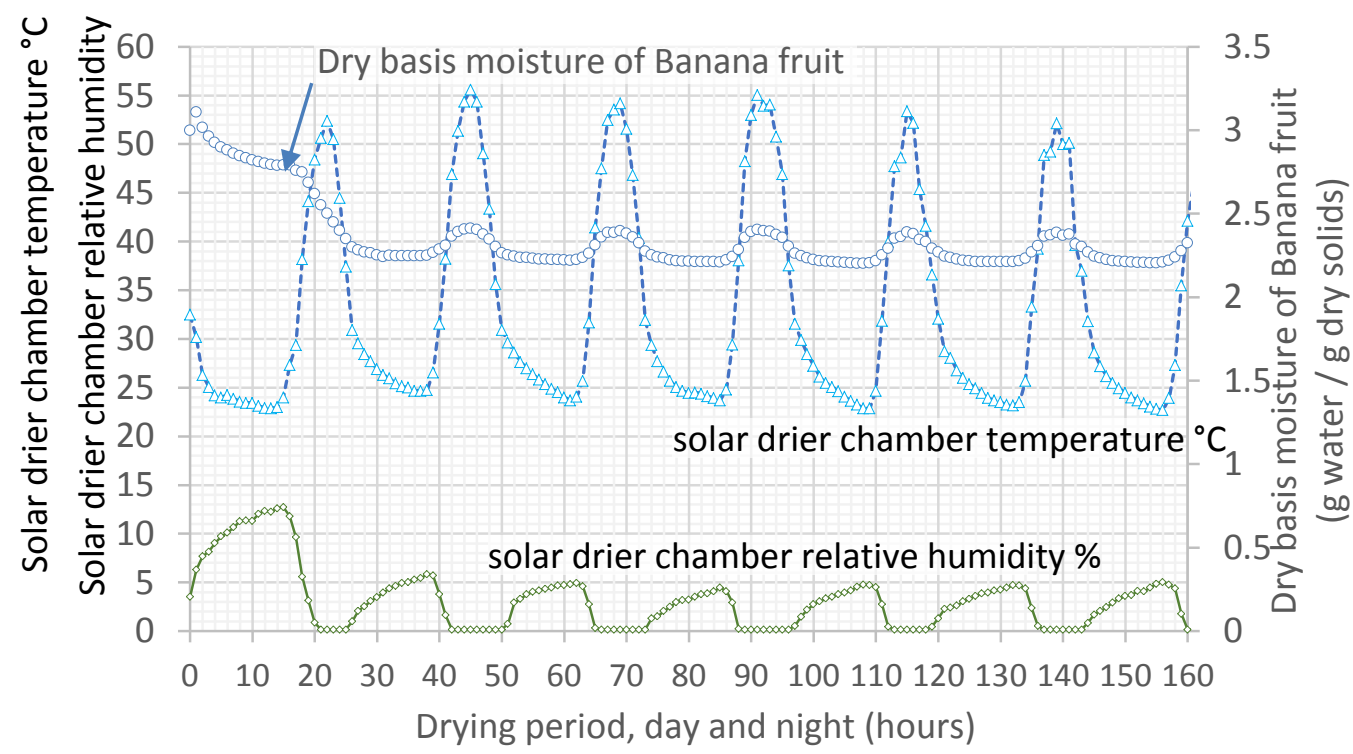

Fig. 23. Relationship between moisture content of banana calculated on dry basis, drier chamber temperature in ${ }^{\circ} \mathrm{C}$, and drying chamber relative humidity percentage

Figure (24) describes the relation of drying rate from the product at different temperature levels in comparison with the solar drier. that the weight of the banana slices decreases faster with the electrical thermal heating temperature at $105^{\circ} \mathrm{C}$ faster than it does for 70 and $50{ }^{\circ} \mathrm{C}$ by $(-0.956,-0.513$, and $-0.55 \mathrm{~g} \mathrm{H} 2 \mathrm{O} / \mathrm{g} \mathrm{dm}$.h)respectively). On the other hand, the solar drier moisture removing rate was much less $(-0.018 \mathrm{~g} \mathrm{H} 2 \mathrm{O} / \mathrm{g} \mathrm{dm}$.h) due to the poor airflow and ability of hot air to remove the right amount of moisture form the sliced banana.

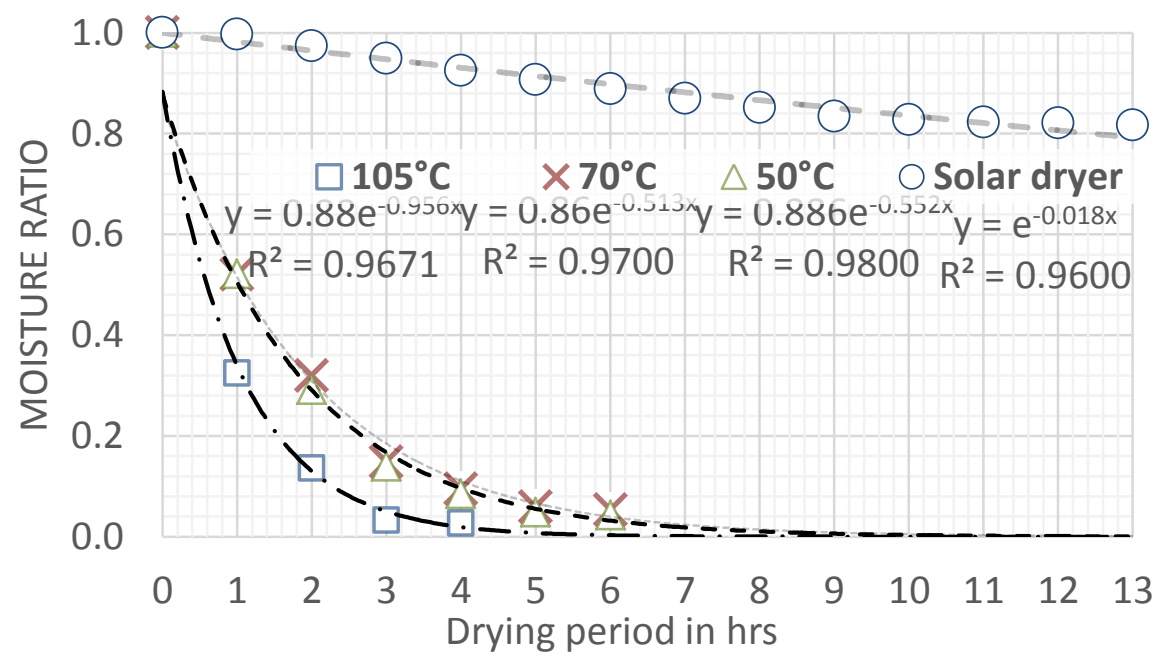

Fig. 24. The experimental solar drier system moisture ratio compared to electrical thermal drying at 50, 70, and $105^{\circ} \mathrm{C}$.

\section{CONCLUSIONS}

Based on the trends presented in this work, it can be concluded that temperature of the drying air, velocity of the drying air. Play a key role in calculation of the rate at which materials dry. Automated measurement and data logging system with a suitable resolution and precision is important 
for monitoring drying process of sliced banana fruit.

The automated measurement system was able to measure and collect data all day and night through the drying period for the entire drying system and was able to work as an effective analytical, troubleshooting, and cause/effect tools. By screening results and dissections, it was found that

1. Drying with natural convection, poor thermal insulation, temperature and relative humidity fluctuations caused a serious drop in drying rate of sliced banana $(-0.018)$ compared with drying with electrical thermal drier $(-0.956$ at $105^{\circ} \mathrm{C},-0.552$ at $70{ }^{\circ} \mathrm{C}$, and -0.513 at $50^{\circ} \mathrm{C}$ ).

2. For natural convection solar drier type it is so important to seal all the ambient air leakage into the drier to eliminate thermal losses and to force the right amount of the air to warmup and dehydrate the desired product, or to supply the solar drier with an air fan to work at forced convection heating principle.

3. To control day and night fluctuation of moisture removal at daytime and gained moisture at night by $\approx 6 \%$ according to the experimental conditions, the solar drier must be equipped by an air-lock gate at the drier entrance. The airlock gate can be controlled by suitable and simple mechanism which can respond to the change of air relative humidity and speed measurements.

4. The recommended drier air-lock mechanism, can control the drier temperature by changing the rate of heat exchange between the product and the hot air for appropriate treatment of thermal sensitive products.

5. It is usually best to have the airflowing across the surface of the material rather than coming in from the bottom of the drier and travelling upwards through the material being dried. This ensures better air distribution and better exposure of the food to the drying air.

6. One problem with drying bananas is that they tend to stick to the wire mesh racks in the drier. For this reason, it is best to use a silicon mesh on which to place the banana slices.

\section{REFERENCES}

Afolabi I.S. 2014. Moisture migration and bulk nutrients interaction in a drying food systems: a review. Food and Nutrition Sci., 58(8), 692714.
Aulakh J. and Regmi A. 2013. Post-Harvest Food Losses Estimation-Development of Consistent Methodology. Rome: FAO, pp. 4-9.

Earle R. 1983. Unit operations in food processing, Second edition, Pregamon Press, Oxford (England) and (USA). pp. 85-104.

El-Ramady H., Domokos-Szabolcsy, E., Abdalla N., Taha H. and Fári M. 2015. Postharvest Management of Fruits and Vegetables Storage. (Sustainable Agriculture Reviews). Springer International Publishing Switzerland, pp. 65152.

FAO 2014. Banana market review and banana statistics 2012-2013. Market and Policy Analyses of Raw Materials, Horticulture and Tropical (RAMHOT) Products Team. Food and Agric. Organization of United Nation, Rome. pp. 1-33.

Hassan M. 2010. A guide to postharvest handling of fruits and vegetables. Dept. of Horticulture Bangladesh Agric. Univ. at Mymensingh, Ali Press, 21, 19-22.

Joardder M.U., Karim A., Kumar C. and Brown R.J. 2014. Determination of effective moisture diffusivity of banana using thermogravimetric analysis. Procedia Engineering, 90, 538-543.

Kawongolo J.B. 2013. Optimization of Processing Technology for Commercial Drying of Bananas (Matooke). (Doctoral Dissertation, Univ. of Kassel, Germany).

Kiaya V. 2014. Post-harvest losses and strategies to reduce them. Technical Paper on Postharvest Losses, Action Contre la Faim (ACF).

Magray M.M., Hussain K., Aijaz M., Singh P. and Nabi A. 2017. Post-harvest management of vegetable crops. J. of Pharmacognosy and Phytochemistry, 6(6), 182-185.

Perumal R. 2007. Comparative performance of solar cabinet, vacuum assisted solar and open sun drying methods. Ph.D. Thesis, Dept. of Bio- resource Engineering, McGill Univ., Montreal, Canada.

Price W.E. 2007. Air-drying of banana: Influence of experimental parameters, slab thickness, banana maturity and harvesting season. J. of Food Engineering, 79(1), 200-207.

Stover R.H. and Simmonds N.W.1987. Classification of banana cultivars. Bananas, Wiley, New York, 3, 86-102.

Struckmann F. 2008. Analysis of a flat-plate solar collector. Heat and Mass Transport, Project Report, 2008MVK160. 


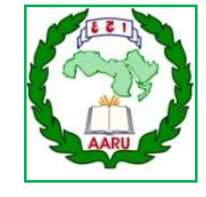

المؤتمر الرابع عثر لبحوث التنمية الزراعية،

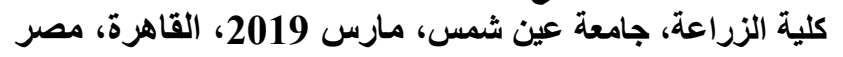

مجلد(27)، عدد(1)، عداعد خاص مارس، 161 - 173، 2019

Website: http://strategy-plan.asu.edu.eg/AUJASCI/

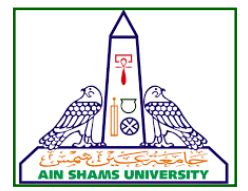

\section{وحده اليه القياس والتسجيل المستمرة لبيانات التجفيف الشمسي لثرائح ثمار الموز}

إنتصار عطية صابر - محمود زكي العطار - مبارك محمد مصطفى - يحيى عبدالرازق هيكل

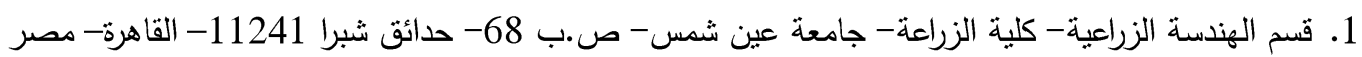

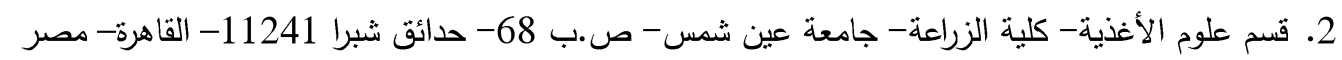

*Corresponding author: entsarelattar1992@yahoo.com

Received 28 February, $2019 \quad$ Accepted 23 March, 2019

الوسائل المستخدمة للقوى الكهربية، بمعدل - 0.956

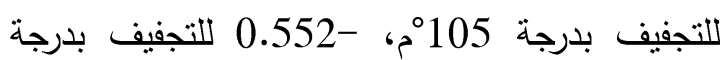

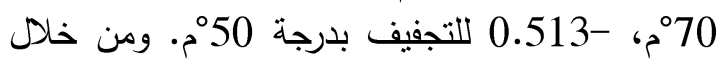
تحليل البيانات المجمعة بواسطة النظام, المقترح والذى سجل البيانات خلال فنترة التجربة نهارا وليلا استنتج الئنج إمكانية تحسين معدلات إزالة الرطوبة من المنات المنتجات

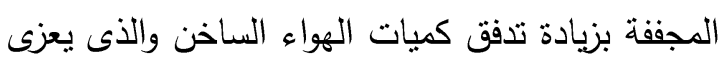

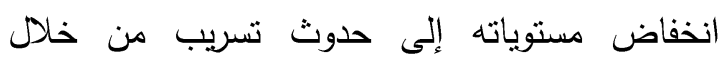
توصيلات المجفف الثمسى، إضافة إلى إعاقة تدفق

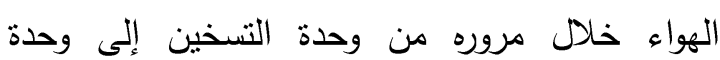

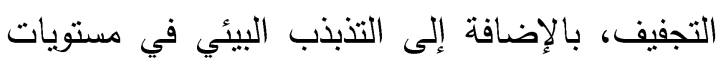
الإثعاع الثمسى ومحتوى الهواء من الرطوبة النئية النسبية.

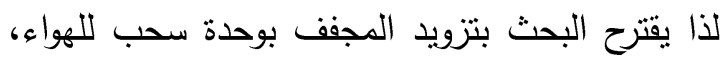
والتحكم في معدلاته بواسطة بوابة تحكم في كميات

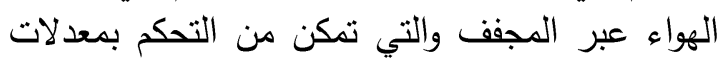
الهواء خلاء عمليات التجفيف وبالتالي التحكم في التحري

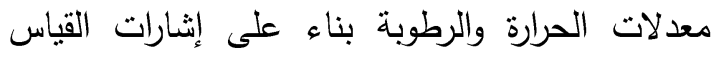
والمعالجة الرقمية للوحدة المقترحة.

الكلمات الدالة: المجفف الثمسي، الموز، وحدة آلية

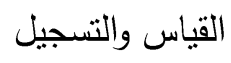

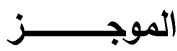

تهدف الدراسة إلى البحث في إمكانيات استخدام

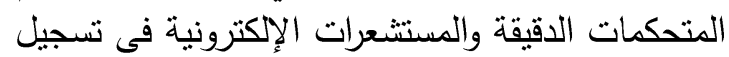

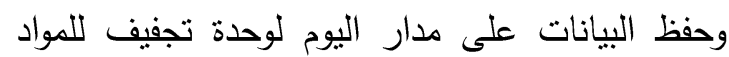

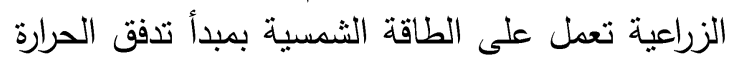

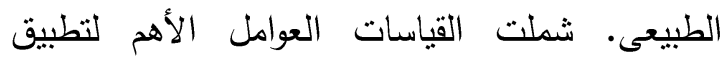

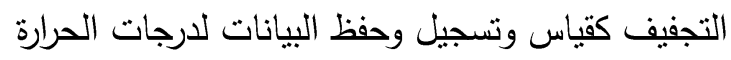

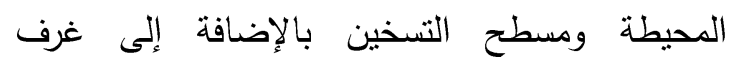
التجفيف. كما شملت القياسات الرطوبة النسبية الجوية الإضية

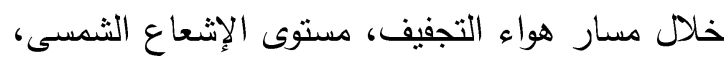

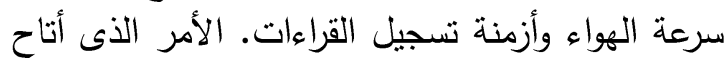

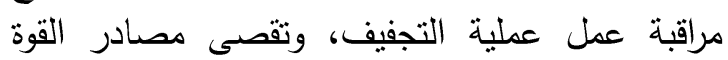
والضعف في الآداء، واقتراح المطلوب من التعديلات

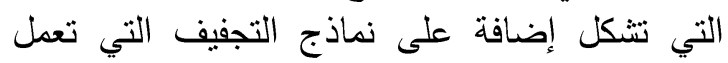
بالطاقة الثمسية. أجريت التجارب على فلى فاكهة الموز

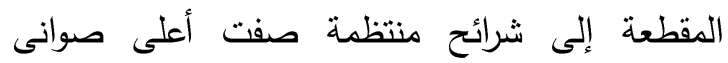
التجفيف المكونة من شبكات تتيح تمرير الهواء بانتظام

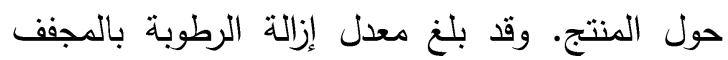

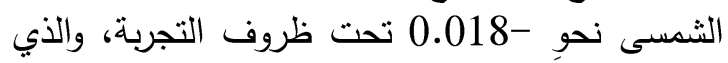
يعد منخفضاً بالمقارنة بمعدلات إزالة الرطوبة باستخدام 